\title{
Hoof quality of Anglo-Arabian and Haflinger horses
}

\author{
Roberto Tocci, Clara Sargentini, Andrea Martini, Luisa Andrenelli, \\ Antonio Pezzati, Doria Benvenuti, Alessandro Giorgetti \\ Department of Agrifood Production and Environmental Sciences - Animal Science Section \\ University of Florence, 50144 Florence, Italy \\ roberto.tocci@unifi.it
}

Received: April 20, $2017 \quad$ Accepted: August 18, 2017

\begin{abstract}
Introduction: Foot quality is essential to the horse's movement. The barefoot approach favours the animal's welfare. Environment and selection determine hoof characteristics. Material and Methods: Hoof characteristics of eight Anglo-Arabian (AA) and nine Haflinger (HA) horses were studied. After a preliminary visual analysis of feet, nail samples were collected after trimming for physico-chemical analysis. The parameters were submitted to analysis of variance. A principal component analysis and a Pearson correlation were used to compare mineral contents. Results: The hooves of both breeds were healthy and solid. The hooves of HA horses were longer than those of AA horses $(14.90 \pm 0.30 \mathrm{~cm} v s 13.10 \pm 0.60 \mathrm{~cm})$, while the AA hoof was harder than the HA hoof both in the wall $(74.55 \pm 2.95 \mathrm{H} v s 60.18 \pm 2.67 \mathrm{H})$ and sole $(67.00 \pm 5.87 \mathrm{H} v s 43.0 \pm 4.76 \mathrm{H})$. In comparison with the sole, the AA hoof wall also had a lower moisture percentage (12.56 $\pm 0.67 \%$ vs $20.64 \pm 0.76 \%$ ), while crude protein and ash contents were similar in both regions. The AA hoof showed a higher Se content, while the HA hoof had a higher level of macroelements. The negative correlations of $\mathrm{K}$ with $\mathrm{Cu}, \mathrm{Fe}, \mathrm{Ni}, \mathrm{Pb}$, and $\mathrm{Zn}$ in the AA hoof may indicate osmoregulation activity. Conclusion: The hoof morphology of AA and HA horses met the literature parameters for mesomorphic horses. Both breeds had healthy and well-conformed hooves, useful for sport and recreation activities.
\end{abstract}

Keywords: horse, Anglo-Arabian, Haflinger, hoof, physico-chemical properties.

\section{Introduction}

Horse movement is governed by the hooves (5). A good foot condition is important in particular in equestrian activities. To promote their animals' welfare, many farmers have kept horses barefoot in recent years. Equine hoof characteristics are an index of environmental adaptability (29). The environment and selection determine the hoof characteristics.

The hoof region stores waste materials, so the nail growth can be considered as a system that works in parallel with other excretory organs and tissues such as the kidneys, skin, and mucous membranes (28). Due to the small surface in contact with the ground, hooves are subjected to heavy loads, and malformations of the keratin structures of the hoof can cause serious motion problems (17). The quality of the keratinised structures of the hoof depends on the availability of necessary minerals, such as calcium, zinc, or copper (17). The horny products of the skin also have the ability to bind heavy metals (23). Previous studies claimed that the soundness of a hoof depends on the arteriovenous activity and on the capacity of the nail to accumulate and excrete waste materials through consumption (19, 21, 30). Amiata donkey, Anglo-Arabian horse, and Monterufoli Pony hooves act as bio-accumulators and as emunctory organs of harmful elements. Because of their relative softness, Monterufoli Pony hooves quickly remove the minerals through nail consumption $(21,30)$.

The aim of this study was to compare the morphological, physical, chemical, and mineral characteristics of hooves of Anglo-Arabian and Haflinger horses reared in Tuscany. The AngloArabian (AA) is a widespread breed used for endurance (15); the Haflinger (HA) horse is a breed native to South Tirol, and it is one of the most common Italian breeds (1). The horses, which were once used in agriculture, are now used as saddle horses. The Haflinger horse was known in the past as a medium 
sized workhorse. In 1873, the breed was improved by introducing Oriental blood and from 1973 there has been a stud book for this breed (1).

\section{Material and Methods}

Animals and experimental design. All experimental procedures were carried out according to Italian law on animal care. This study was performed in the "Corpo Forestale dello Stato" Tuscan farms, and it involved eight (four males and four females) AA horses $(9.0 \pm 4.2$ years of age and $543.4 \pm 17.9 \mathrm{~kg}$ of live weight) and nine (four males and five females) HA horses $(6.0 \pm 0.8$ years of age and $515.7 \pm 20.4 \mathrm{~kg}$ of live weight). The horses were reared in boxes with paddocks and were fed with local hay and straw, a mixture of barley and maize, and received water ad libitum. The trial was performed during the autumn and winter. The horses were trained on ground for two hours a day.

Morphological and physical analysis. During hoof shaving, a visual analysis was performed in order to check the nail characteristics. The morphology of the front left hoof was evaluated. The circumferences of the coronet and the bottom edge of the foot were measured and their relationship was calculated as the conicity index $(\mathrm{CI})(5,21)$. The hardness $\left(\mathrm{H}, \mathrm{kg} / \mathrm{mm}^{2}\right)$ of the wall, white line, and sole were measured following the methodology used by Tocci et al. (30).

Chemical analysis. Samples of wall and sole were taken from both breeds during the hoof shaving. Eight wall samples and six sole samples from AA horses, and nine wall samples and nine sole samples from HA horses were obtained and analysed.

After a water and ethyl alcohol wash (9), the samples were pre-dried $\left(60^{\circ} \mathrm{C} / 24 \mathrm{~h}\right)$ following the methods of Tocci et al. (30). The samples were crushed with an electric mill (21). The moisture of both hoof regions was determined through drying in a stove $\left(105^{\circ} \mathrm{C} / 4 \mathrm{~h}\right)$. The EU official methodologies (First Commission Directive 71/250 EEC of 15 June 1971 OJ L 155/20, 12.7.1971) were used to determine the ashes. The total crude protein (CP) was determined with the Kjeldahl CEE-ASPA method (16).

Mineralogical analysis. The hoof mineral quantitative analyses were performed in the Florence University laboratories (30). Calcium (Ca), potassium $(\mathrm{K})$, magnesium $(\mathrm{Mg})$, sodium $(\mathrm{Na})$, phosphorous $(\mathrm{P})$, copper $(\mathrm{Cu})$, iron $(\mathrm{Fe})$, manganese $(\mathrm{Mn})$, selenium $(\mathrm{Se})$, zinc $(\mathrm{Zn})$, nickel $(\mathrm{Ni})$, aluminium $(\mathrm{Al})$, lithium $(\mathrm{Li})$, lead $(\mathrm{Pb})$, and strontium $(\mathrm{Sr})$ were determined

Statistical analysis. Data were analysed with JMP 10 statistical software (22). The hoof morphological and physical characteristics were submitted to one-way ANOVA for unbalanced data, considering the breed as fixed effects. The chemical and mineralogical composition results were submitted to two-way ANOVA, considering as fixed effects the breed, hoof region, and their interaction. Differences among means were calculated with Student's $t$-test. The Pearson correlation coefficients were used to measure the strength of a linear association between the mean hoof $\mathrm{H}$ and the mean hoof moisture content. The reciprocal correlation between minerals in AA and HA hooves was also calculated.

Principal component analysis (PCA) was applied in this study. PCA is a procedure for identifying a smaller number of uncorrelated variables, called "principal components", from a large set of data. This method was used to determine the degree of similarity between the mineral content of the hooves of AA and HA horses, and between the mineral content in the wall and sole of both breeds.

The Kaiser criterion was applied. This method retains only factors with eigenvalues greater than 1 . This criterion was proposed by the psychometrician whose name it bears (11), and is probably the one most widely used. The Varimax rotation was carried out. This method is a way of transforming the solution so that the rotated component matrix is relatively easy to understand (11). The loading and the score plots were also performed in order to visualise the mineral distribution in the hooves of both breeds and in both hoof regions.

\section{Results}

Visual and morphological analysis and physical characteristics. AA and HA horses showed well conformed and healthy hooves. Their hooves were solid and the nail integrated. The CI, wall, and white line thickness were similar in both breeds. The foot length was greater in HA horses. The sole and wall were harder in AA hooves (Table 1).

Chemical composition. The chemical composition of the nail (Table 2) showed how all the considered parameters were in ranges defined by hoof region and not by breed. Moisture content was higher in the sole, while CP and ash contents were higher in the wall. No significant interactions were found among chemical parameters. The correlation between moisture content in the wall and sole and their respective $\mathrm{H}$ was not significant (correlation coefficient in wall $\mathrm{P}=0.34, \mathrm{P}=0.13$, n.s.; correlation coefficient in sole $\mathrm{P}=0.13$, $\mathrm{P} 0.65$, n.s.).

Mineral composition. Se content was higher in AA hooves, while $\mathrm{K}, \mathrm{Mn}, \mathrm{Li}, \mathrm{P}$, and $\mathrm{Sr}$ contents were higher in HA hooves (Table 3). In the hoof regions, only $\mathrm{Al}$ content was higher in the sole, while the rest of the elements' contents were heavier in the wall. Ca, $\mathrm{K}, \mathrm{Li}, \mathrm{Mg}$, and $\mathrm{Mn}$ contents were different in the interactions between breed and hoof region (Table 3 ).

The HA hoof wall yielded the highest content of all the studied minerals, while the AA hoof wall often returned lower values (Table 4). The HA sole held 
lower mineral content with only the content of $\mathrm{Li}$ higher and similar to that of the wall. The AA sole concentrated minerals more sparsely.

The Kaiser test arrived at five eigenvalues that reached more than $79 \%$ of the total variability; Principal Component 1 (PC1) showed 33.54\%, while Principal Component 2 (PC2) was next highest at 19.8\% (Table 5).

Using Varimax rotation the following elements were identified in factor $1: \mathrm{Ca}, \mathrm{K}, \mathrm{Mg}, \mathrm{Fe}, \mathrm{Mn}, \mathrm{Ni}$, and $\mathrm{Sr}$. Rotation for factor 2 provided $\mathrm{P}, \mathrm{Cu}, \mathrm{Fe}, \mathrm{Se}, \mathrm{Ni}, \mathrm{Pb}$, and $\mathrm{Sr}$ (Table 6).

In the loading and score plots of the mineral content in the hooves of both breeds, PC2 discriminated AA from HA breed better than PC1 (Fig. 1). The AA hoof was identified mainly by $\mathrm{Cu}, \mathrm{Fe}, \mathrm{Se}$, and $\mathrm{Pb}$, while the HA hoof was identified by $\mathrm{Ca}, \mathrm{K}, \mathrm{Mg}$, and $\mathrm{P}$.

In the loading and score plots of content by hoof regions (Fig. 2), wall and sole were quite distinct in PC1; most minerals identified the wall, and only $\mathrm{Al}$ identified the sole.

The Pearson correlation of the mineral content in the AA hoof (Table 7) revealed that $\mathrm{Al}, \mathrm{Cu}, \mathrm{Fe}, \mathrm{Ni}, \mathrm{Pb}$, and $\mathrm{Sr}$ had higher numbers of significant correlations. The significant correlations of $\mathrm{Al}$ were almost all negative, except with $\mathrm{Na}$. In the HA hoof (Table 8) the elements with higher numbers of significant correlations were $\mathrm{Ca}, \mathrm{Cu}, \mathrm{K}, \mathrm{Mg}, \mathrm{Mn}$, and Sr. Only $\mathrm{Al}$ had negative correlations, while usually the significant correlations among the elements were positive.

Table 1. Morphological and physical characteristics of hoof of AA and HA horses (means \pm SEM)

\begin{tabular}{llll}
\hline & Unit & AA & HA \\
\hline Foot length & $\mathrm{cm}$ & $13.1 \pm 0.6 \mathrm{~b}$ & $14.9 \pm 0.3 \mathrm{a}$ \\
Foot width & $\mathrm{cm}$ & $12.7 \pm 0.3$ & $13.3 \pm 0.2$ \\
Width foot/length foot & & $0.94 \pm 0.02$ & $0.89 \pm 0.01$ \\
Crown circumference & $\mathrm{cm}$ & $36.0 \pm 1.38$ & $38.7 \pm 0.6$ \\
Solar circumference & $\mathrm{cm}$ & $42.0 \pm 1.28$ & $44.2 \pm 0.77$ \\
CI & & $0.83 \pm 0.02$ & $0.87 \pm 0.01$ \\
Sole H D & $\mathrm{H}$ & $67.0 \pm 5.87 \mathrm{~A}$ & $43.0 \pm 4.76 \mathrm{~B}$ \\
White line H D & $\mathrm{H}$ & $26.55 \pm 3.82$ & $31.55 \pm 3.82$ \\
Wall H D & $\mathrm{H}$ & $74.55 \pm 2.95 \mathrm{~A}$ & $60.18 \pm 2.67 \mathrm{~B}$ \\
Wall thickness & $\mathrm{mm}$ & $10.6 \pm 0.4$ & $12.4 \pm 0.7$ \\
White line thickness & $\mathrm{mm}$ & $4.8 \pm 0.3$ & $4.3 \pm 0.3$ \\
\hline
\end{tabular}

$\mathrm{a}, \mathrm{b}-\mathrm{P}<0.05 ; \mathrm{A}, \mathrm{B}-\mathrm{P}<0.01$

Table 2. Chemical composition of AA and HA hooves (means \pm SEM)

\begin{tabular}{llllll}
\hline & & \multicolumn{2}{c}{ BREED } & \multicolumn{2}{c}{ HOOF } \\
\cline { 3 - 6 } & & AA & HA & WALL & SOLE \\
\hline Moisture & $\%$ & $16.89 \pm 0.77$ & $16.7 \pm 0.64$ & $12.56 \pm 0.67 \mathrm{~B}$ & $20.64 \pm 0.76 \mathrm{~A}$ \\
CP & $\%$ on DM & $97.14 \pm 0.44$ & $97.87 \pm 0.95$ & $97.14 \pm 0.44$ & $98.41 \pm 0.44$ \\
Ashes & \% on DM & $1.43 \pm 0.13$ & $1.18 \pm 0.15$ & $1.17 \pm 0.13$ & $1.44 \pm 0.14$ \\
\hline
\end{tabular}

$\mathrm{A}, \mathrm{B}-\mathrm{P}<0.01$

Table 3. Mineral composition (ppm) of hoof in relation to breed and hoof region (wall and sole) (means \pm SEM)

\begin{tabular}{|c|c|c|c|c|c|}
\hline & \multicolumn{2}{|c|}{ BREED } & \multicolumn{2}{|c|}{ HOOF REGION } & \multirow[t]{2}{*}{$\mathrm{B} \times \mathrm{HR}^{1}$} \\
\hline & $\mathrm{AA}$ & HA & WALL & SOLE & \\
\hline $\mathrm{Al}$ & $524.33 \pm 106.9$ & $343.9 \pm 9.5$ & $237.6 \pm 99.3 \mathrm{~B}$ & $630.6 \pm 108.4 \mathrm{~A}$ & n.s. \\
\hline $\mathrm{Ca}$ & $1156.0 \pm 140.03$ & $1216.5 \pm 108.3$ & $1466.7 \pm 120.7 \mathrm{~A}$ & $905.8 \pm 131.8 \mathrm{~B}$ & $* *$ \\
\hline $\mathrm{Cu}$ & $5.3 \pm 0.7$ & $3.9 \pm 0.6$ & $5.7 \pm 0.6 \mathrm{a}$ & $3.6 \pm 0.6 \mathrm{~b}$ & n.s. \\
\hline $\mathrm{Fe}$ & $1620.4 \pm 452.0$ & $1385.3 \pm 346.8$ & $2509.0 \pm 388.9 \mathrm{~A}$ & $496.6 \pm 494.8 \mathrm{~B}$ & n.s. \\
\hline K & $1348.2 \pm 214.8 \mathrm{~B}$ & $2606.0 \pm 166.3 \mathrm{~A}$ & $2201.4 \pm 175.3$ & $1777.5 \pm 201.9$ & $* *$ \\
\hline $\mathrm{Li}$ & $0.41 \pm 0.04 \mathrm{~B}$ & $0.61 \pm 0.04 \mathrm{~A}$ & $0.7 \pm 0.04 \mathrm{~A}$ & $0.4 \pm 0.04 \mathrm{~B}$ & $* * *$ \\
\hline $\mathrm{Mg}$ & $305.6 \pm 39.9$ & $322.8 \pm 31.0$ & $373.0 \pm 32.7 \mathrm{~A}$ & $255.4 \pm 37.5 \mathrm{~B}$ & $* * *$ \\
\hline $\mathrm{Mn}$ & $99.6 \pm 40.0 \mathrm{~B}$ & $246.1 \pm 31.1 \mathrm{~A}$ & $325.9 \pm 34.4 \mathrm{~A}$ & $19.8 \pm 37.6 \mathrm{~B}$ & $* *$ \\
\hline $\mathrm{Na}$ & $396.2 \pm 60.0$ & $311.7 \pm 46.4$ & $379.0 \pm 51.6$ & $328.9 \pm 56.3$ & n.s. \\
\hline $\mathrm{Ni}$ & $3.6 \pm 0.7$ & $3.1 \pm 0.5$ & $5.5 \pm 0.6 \mathrm{~A}$ & $1.1 \pm 0.7 \mathrm{~B}$ & n.s. \\
\hline $\mathrm{P}$ & $179.9 \pm 32.4 \mathrm{~B}$ & $303.1 \pm 25.6 \mathrm{~A}$ & $263.4 \pm 27.9$ & $219.6 \pm 30.4$ & n.s. \\
\hline $\mathrm{Pb}$ & $2.2 \pm 0.4$ & $2.2 \pm 0.3$ & $2.7 \pm 0.3$ & $1.7 \pm 0.3$ & n.s. \\
\hline $\mathrm{Se}$ & $1.2 \pm 0.2 \mathrm{a}$ & $0.5 \pm 0.2 \mathrm{~b}$ & $1.2 \pm 0.2 \mathrm{a}$ & $0.4 \pm 0.2 \mathrm{~b}$ & n.s. \\
\hline $\mathrm{Sr}$ & $3.1 \pm 0.5 \mathrm{~B}$ & $4.9 \pm 0.4 \mathrm{~A}$ & $5.6 \pm 0.5 \mathrm{~A}$ & $2.4 \pm 0.5 \mathrm{~B}$ & n.s. \\
\hline $\mathrm{Zn}$ & $126.4 \pm 6.9$ & $107.3 \pm 5.7$ & $131.5 \pm 6.3 \mathrm{~A}$ & $102.1 \pm 6.9 \mathrm{~B}$ & n.s. \\
\hline
\end{tabular}

\footnotetext{
${ }^{1}$ breed and hoof region interaction; $\mathrm{a}, \mathrm{b}-\mathrm{P}<0.05 ; \mathrm{A}, \mathrm{B}-\mathrm{P}<0.01$
} 
Table 4. Mineral content: breeds and hoof region interactions (means $\pm \mathrm{SEM}$ )

\begin{tabular}{|c|c|c|c|c|}
\hline & \multicolumn{2}{|c|}{ AA } & \multicolumn{2}{|c|}{ HA } \\
\hline & WALL & SOLE & WALL & SOLE \\
\hline \multicolumn{5}{|c|}{ Macroelement } \\
\hline $\mathrm{Ca}$ & $1242.2 \pm 183.7 \mathrm{AB}$ & $1069.8 \pm 212.1 \mathrm{AB}$ & $1691.1 \pm 153.2 \mathrm{~A}$ & $741.9 \pm 156.6 \mathrm{~B}$ \\
\hline $\mathrm{K}$ & $1242.9 \pm 281.2 \mathrm{~B}$ & $1453.5 \pm 324.8 \mathrm{~B}$ & $3110.5 \pm 239.8 \mathrm{~A}$ & $2101.4 \pm 239.8 \mathrm{~B}$ \\
\hline $\mathrm{Mg}$ & $274.9 \pm 52.2 \mathrm{~B}$ & $336.3 \pm 60.3 \mathrm{AB}$ & $471.0 \pm 44.5 \mathrm{~A}$ & $174.5 \pm 44.5 \mathrm{~B}$ \\
\hline \multicolumn{5}{|c|}{ Trace element } \\
\hline $\mathrm{Li}$ & $0.6 \pm 0.06 \mathrm{~A}$ & $0.17 \pm 0.07 \mathrm{~B}$ & $0.7 \pm 0.05 \mathrm{~A}$ & $0.5 \pm 0.05 \mathrm{~A}$ \\
\hline Mn & $180.8 \pm 52.4 \mathrm{~B}$ & $18.4 \pm 60.5 \mathrm{C}$ & $471.1 \pm 44.7 \mathrm{~A}$ & $21.1 \pm 44.7 \mathrm{C}$ \\
\hline
\end{tabular}

$\mathrm{A}, \mathrm{B}-\mathrm{P}<0.01$

Table 5. Results from the principal component analysis for the first five principal components

\begin{tabular}{llll}
\hline Number & Eigenvalue & Percentage & Cumulative percentage \\
\hline 1 & 5.03 & 33.54 & 33.54 \\
2 & 2.97 & 19.8 & 53.34 \\
3 & 1.69 & 11.25 & 64.59 \\
4 & 1.19 & 7.94 & 72.53 \\
5 & 1.01 & 6.76 & 79.29 \\
\hline
\end{tabular}

Table 6. Correlation coefficient after Varimax rotation for minerals determined for AA and HA hooves and hoof region

\begin{tabular}{llllll}
\hline & Factor 1 & Factor 2 & Factor 3 & Factor 4 & Factor 5 \\
\cline { 2 - 6 } $\mathrm{Al}$ & -0.15 & -0.17 & -0.16 & -0.41 & 0.72 \\
$\mathrm{Ca}$ & 0.7 & 0.09 & 0.27 & 0.48 & 0.11 \\
$\mathrm{Cu}$ & 0.03 & 0.85 & 0.15 & 0.16 & 0.05 \\
$\mathrm{Fe}$ & 0.5 & 0.42 & 0.52 & -0.31 & -0.2 \\
$\mathrm{~K}$ & 0.63 & -0.17 & -0.28 & 0.31 & 0.24 \\
$\mathrm{Li}$ & 0.2 & 0.16 & 0.08 & 0.77 & -0.1 \\
$\mathrm{Mg}$ & 0.91 & -0.05 & 0.05 & 0.02 & -0.09 \\
$\mathrm{Mn}$ & 0.91 & -0.04 & 0.13 & 0.18 & -0.13 \\
$\mathrm{Na}$ & -0.04 & 0.22 & 0.08 & 0.04 & 0.88 \\
$\mathrm{Ni}$ & 0.63 & 0.54 & 0.25 & -0.1 & -0.1 \\
$\mathrm{P}$ & 0.32 & -0.44 & -0.27 & 0.58 & -0.1 \\
$\mathrm{~Pb}$ & 0.05 & 0.83 & -0.001 & -0.01 & 0.02 \\
$\mathrm{Se}$ & -0.12 & 0.36 & 0.64 & -0.17 & -0.47 \\
$\mathrm{Sr}$ & 0.85 & 0.35 & -0.03 & 0.3 & -0.08 \\
$\mathrm{Zn}$ & 0.16 & 0.01 & 0.9 & 0.16 & 0.1 \\
\hline
\end{tabular}

Table 7. Significant Pearson correlation coefficient among minerals in AA hoof

\begin{tabular}{|c|c|c|c|c|c|c|c|c|c|c|c|c|c|c|c|}
\hline & $\mathrm{Al}$ & $\mathrm{Ca}$ & $\mathrm{Cu}$ & $\mathrm{Fe}$ & $\mathrm{K}$ & $\mathrm{Li}$ & $\mathrm{Mg}$ & $\mathrm{Mn}$ & $\mathrm{Na}$ & $\mathrm{Ni}$ & $\mathrm{P}$ & $\mathrm{Pb}$ & $\mathrm{Se}$ & $\mathrm{Sr}$ & $\mathrm{Zn}$ \\
\hline $\mathrm{Al}$ & 1.0 & & & & & & & & & & & & & & \\
\hline $\mathrm{Ca}$ & -0.54 & 1.0 & & & & & & & & & & & & & \\
\hline $\mathrm{Cu}$ & -0.32 & 0.39 & 1.0 & & & & & & & & & & & & \\
\hline $\mathrm{Fe}$ & -0.34 & 0.05 & 0.34 & 1.0 & & & & & & & & & & & \\
\hline $\mathrm{K}$ & 0.09 & 0.03 & -0.37 & -0.30 & 1.0 & & & & & & & & & & \\
\hline $\mathrm{Li}$ & -0.27 & 0.44 & 0.16 & 0.47 & -0.14 & 1.0 & & & & & & & & & \\
\hline $\mathrm{Mg}$ & -0.38 & 0.54 & -0.08 & -0.30 & 0.10 & -0.25 & 1.0 & & & & & & & & \\
\hline $\mathrm{Mn}$ & -0.24 & 0.38 & -0.11 & 0.39 & 0.26 & 0.55 & 0.12 & 1.0 & & & & & & & \\
\hline $\mathrm{Na}$ & 0.49 & 0.00 & 0.36 & -0.08 & 0.34 & 0.01 & -0.34 & -0.02 & 1.0 & & & & & & \\
\hline $\mathrm{Ni}$ & -0.21 & 0.15 & 0.59 & 0.82 & -0.30 & 0.58 & -0.39 & 0.35 & 0.18 & 1.0 & & & & & \\
\hline $\mathrm{P}$ & 0.05 & -0.05 & -0.56 & -0.15 & -0.14 & -0.12 & 0.35 & 0.12 & -0.35 & -0.39 & 1.0 & & & & \\
\hline $\mathrm{Pb}$ & -0.13 & -0.09 & 0.61 & 0.45 & -0.43 & 0.18 & -0.47 & -0.30 & 0.17 & 0.37 & -0.45 & 1.0 & & & \\
\hline $\mathrm{Se}$ & -0.38 & -0.25 & -0.08 & 0.55 & 0.12 & 0.15 & -0.11 & 0.46 & -0.35 & 0.28 & -0.12 & 0.21 & 1.0 & & \\
\hline $\mathrm{Sr}$ & -0.45 & 0.48 & 0.83 & 0.53 & -0.24 & 0.45 & -0.09 & 0.22 & 0.27 & 0.68 & -0.44 & 0.59 & 0.15 & 1.0 & \\
\hline $\mathrm{Zn}$ & -0.48 & 0.11 & 0.07 & 0.63 & -0.38 & 0.37 & 0.06 & 0.56 & -0.60 & 0.53 & 0.10 & -0.01 & 0.60 & 0.32 & 1.0 \\
\hline
\end{tabular}


Table 8. Significant Pearson correlation coefficient among minerals in HA hoof

\begin{tabular}{lccccccccccccccccc}
\hline & $\mathrm{Al}$ & $\mathrm{Ca}$ & $\mathrm{Cu}$ & $\mathrm{Fe}$ & $\mathrm{K}$ & $\mathrm{Li}$ & $\mathrm{Mg}$ & $\mathrm{Mn}$ & $\mathrm{Na}$ & $\mathrm{Ni}$ & $\mathrm{P}$ & $\mathrm{Pb}$ & $\mathrm{Se}$ & $\mathrm{Sr}$ & $\mathrm{Zn}$ \\
\hline $\mathrm{Al}$ & 1.00 & & & & & & & & & & & \\
$\mathrm{Ca}$ & -0.24 & 1.00 & & & & & & & & & \\
$\mathrm{Cu}$ & -0.35 & 0.68 & 1.00 & & & & & & & & \\
$\mathrm{Fe}$ & -0.25 & 0.36 & 0.35 & 1.00 & & & & & & & \\
$\mathrm{~K}$ & 0.01 & 0.65 & 0.44 & 0.22 & 1.00 & & & & & & & \\
$\mathrm{Li}$ & -0.38 & 0.60 & 0.41 & -0.16 & 0.38 & 1.00 & & & & & \\
$\mathrm{Mg}$ & -0.28 & 0.72 & 0.37 & 0.54 & 0.61 & 0.32 & 1.00 & & & & \\
$\mathrm{Mn}$ & -0.36 & 0.71 & 0.36 & 0.56 & 0.56 & 0.35 & 0.96 & 1.00 & & & \\
$\mathrm{Na}$ & 0.45 & 0.06 & -0.05 & -0.04 & 0.34 & 0.17 & -0.05 & -0.01 & 1.00 & & & \\
$\mathrm{Ni}$ & -0.25 & 0.58 & 0.51 & 0.65 & 0.49 & 0.09 & 0.81 & 0.80 & -0.16 & 1.00 & & \\
$\mathrm{P}$ & -0.19 & 0.39 & -0.13 & -0.31 & 0.23 & 0.42 & 0.32 & 0.34 & -0.09 & -0.04 & 1.00 & \\
$\mathrm{~Pb}$ & 0.01 & 0.29 & 0.36 & 0.51 & 0.39 & -0.09 & 0.34 & 0.25 & 0.08 & 0.42 & -0.38 & 1.00 \\
$\mathrm{Se}$ & -0.04 & 0.30 & 0.44 & -0.03 & 0.19 & 0.32 & 0.05 & 0.13 & 0.31 & 0.30 & -0.03 & -0.03 & 1.00 \\
$\mathrm{Sr}$ & -0.30 & 0.85 & 0.56 & 0.56 & 0.62 & 0.42 & 0.90 & 0.90 & -0.10 & 0.80 & 0.29 & 0.31 & 0.18 & 1.00 \\
$\mathrm{Zn}$ & -0.16 & 0.58 & 0.31 & 0.38 & 0.31 & 0.19 & 0.26 & 0.29 & 0.26 & 0.15 & 0.09 & 0.31 & 0.01 & 0.30 & 1.00 \\
\hline
\end{tabular}
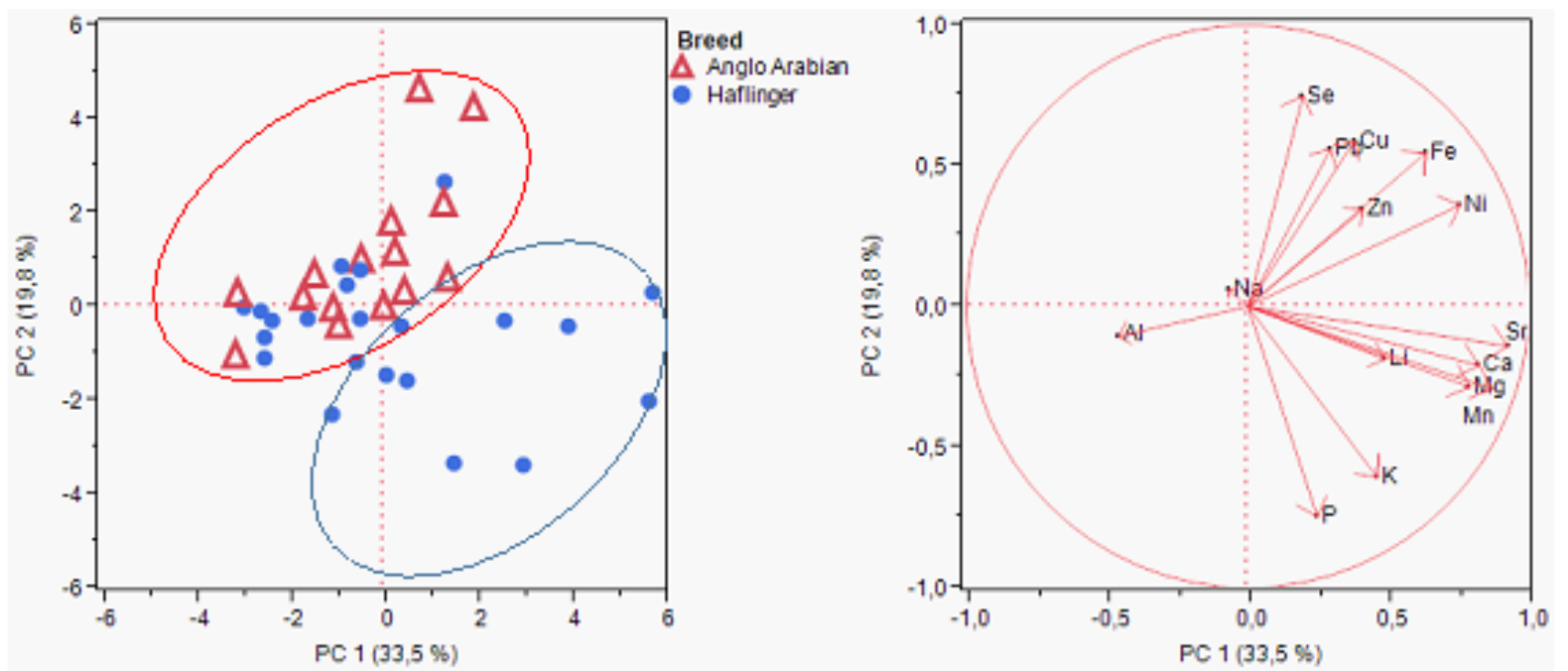

Fig. 1. Score and loading plot for PCA of AA and HA hooves
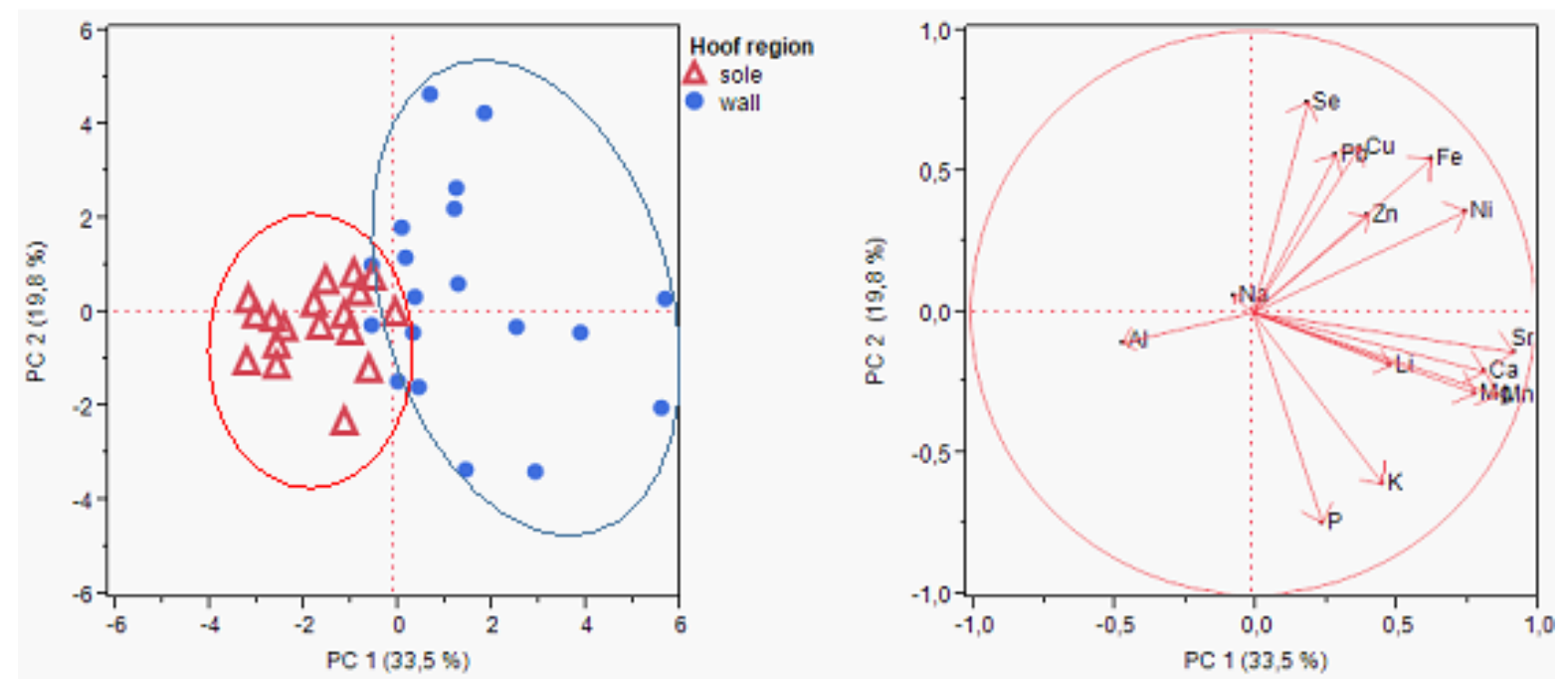

Fig. 2. Score and loading plot for PCA of wall and sole of both breeds 


\section{Discussion}

Visual and morphological analysis and physicochemical composition. The AA hoof was solid and hard, because this breed derives from Arabian horses, adapted to the desert environment (24). The robustness of AA hooves in the current study did not concur with the results of Łuszczyński et al. (14), who found problems in the hoof of this breed, mainly in the white line. The same characteristics were found in the HA hoof as in the AA counterpart, as also in their Arabian ancestors (10). The CI was not different from the values of mesomorphic/dolicomorphic horses, indicating an ideal ratio of 5/6 (5). The wall thickness was measured at lower values than those found by Corley and Stephen (8). Wall thickness of both breeds was similar to values for this parameter found by Stachurska et al. (26) and Tocci et al. (30). The white line thickness was wider than the $3 \mathrm{~mm}$ claimed as the average value by Smith Thomas (24), but the line had uniform width all around the sole and was free from defects or damage.

The length and the width of the AA hoof were similar to those found by Stachurska et al. (27), while the width to length ratio and the wall thickness were a little lower in this study. The crown circumference of both breeds was larger than that of the Crioulo breed, having the same morphological characteristics (25). The AA wall $\mathrm{H}$ was in line with that found by Pütz (18).

The HA wall $\mathrm{H}$ supported the results found by Coenen and Spizlei (7) and by Pütz (18). Hardness in the sole of AA and HA hooves was lower than in the wall. The horn of the sole differed from the horn of the wall, but it was soft, moist, and elastic (6). The white line, the germinative layer of nail, was the softer region of the hoof. Narrowness of the white line is important for both breeds, because it represents the conjunction of wall, sole, and inner hoof, and is more susceptible to infections (4).

Moisture content affects the mechanical characteristics, influencing nail health and affecting its water-soluble substances. The absorption capacity of the sole is determined by its moisture, especially close to the white line. A low storage capacity is an attribute of the sole (3). The moisture content found in this trial was lower than results reported in the literature $(18,3)$. This study was performed in a Mediterranean area, where the dry periods can affect the water content of the nail. According to some authors, $\mathrm{H}$ is positively correlated to moisture (3), while an average water content leads to an elastic nail, and too dry or too wet nails are less elastic (3) and consequently more prone to damage (31).

The CP content was higher than literature results $(9,12)$. The nail ash evaluated in this trial was similar to that of equines raised in Tuscan farms (30), but lower than that of Brazilian horses (9).
Mineral composition. The $\mathrm{Mn}$ content in the soles of both breeds was similar to that found by Stachurska et al. (27), while AA and HA hooves presented higher $\mathrm{Cu}$ and $\mathrm{Pb}$ contents. The mineral content in both breeds was similar to the results of Ley et al. (13) for Thoroughbred hooves, and only $\mathrm{Mn}$ content was higher and $\mathrm{P}$ was lower in AA and HA hooves. $\mathrm{Na}$ and $\mathrm{K}$ are involved in cellular osmoregulation, having an active role in the $\mathrm{Na} / \mathrm{K}$ pump $(2,20) . \mathrm{K}$ in the AA hoof probably played a role in the osmoregulation activity because the negative correlations with many elements are also dangerous. The Pearson positive correlation of mineral content in the HA hoof seemed to indicate low osmoregulatory activity.

In summary, the considered hooves were healthy and well conformed, with morphology that reflected the literature parameters for mesomorphic horses. Foot length in HA hooves exceeded that in AA hooves while hardness of the sole and wall in AA hooves surpassed that of HA hooves. The hooves of both breeds had lower moisture content than the hooves of North European horses studied by other authors. As expected, soles contained less moisture than walls, while walls contained more mineral traces, except for Al. The AA hoof was identified mainly by trace elements, while the HA hoof was identified by macroelements. The majority of the negative correlations of the AA hoof, especially for $\mathrm{K}$, seemed to indicate high osmoregulatory activity. The hoof quality of AA and HA horses recommends the selection of both breeds for equestrian activities which test endurance.

Conflict of Interests Statement: The authors declare that there is no conflict of interests regarding the publication of this article.

Financial Disclosure Statement: This work was supported by Tuscany Region - General Directorate for Economic Development, and Project for characterisation and productive recovery of equine breeds; Grosseto and Pisa Provinces: VAGAL (Valorisation of local genotypes) - Cross-border cooperation programme Italy-France "Maritime 20072013”.

Animal Rights Statement: The authors declare that the trials on animals were conducted in accordance with local Ethical Committee laws and regulations as regards care of animals.

\section{References}

1. A.N.AC.R.HA.I.: Il cavallo Haflinger nel paese di origine. Available in: http://www.haflinger.it/test/index.php?option= com_content\&view=article\&id=49\&Itemid=111\&lang=it, 2017.

2. Bentley P.J.: Endocrines and osmoregulation. A comparative account in vertebrates. Springer Science \& Business Media, Nedlands, Western Australia, 2002. 
3. Bertram J.E.A., Gosline J.M.: Functional design of horse hoof keratin: the modulation of mechanical properties through hydration effects. J Exp Biol 1987, 130, 121-136.

4. Budras K.D., Geyer H.: Elektronenmikroskopische Untersuchungen über abnorm verändertes Horn in der Schutzschicht des Pferdehufes. Anat Histol Embryol 1989, 18, 268.

5. Catalano A.L.: Valutazione morfo-funzionale del cavallo Igiene ed Etnologia. Goliardica Editrice, Noceto (PR), Italy, 1984.

6. Clarendon T.: The foot of the horse; its structure and functions: with the means preserving its healthy action and of its diseases, by a new method of shoeing. In: The Anatomy of the Horse's Foot and Hoof - A collection of historical articles on the physiology and the function of the foot and hoof. Varios, Read books Ltd, Evesham St, Redditch, United Kingdom, 2011.

7. Coenen M., Spitzlei S.: Zur Zusammensetzung des Hufhorns in Abhängigkeit von Alter, Rasse und Hufhornqualität. Pferdeheilkunde 1996, 12, 279-283.

8. Corley K., Stephen J.: The Equine Hospital Manual. WileyBlackwell, Hoboken, New Jersey, USA, 2008.

9. Faria G.A., Rezende A.S.C., Sampaio I.B.M., Lana A.M.Q., Moura R.S., Madureira J.S., Resende M.C.:Composição quimica dos cascos de eqüinos das raças Pantaneira e Mangalarga Marchador. Arq Bras Med Vet Zootec 2005, 57, 697-701.

10. Gandini G.C., Samorè A., Pagnacco G.: Genetic contribution of the Arabian to the Italian Haflinger horse. J Anim Breed Genet 1997, 114, 457-464.

11. Kaiser H.F.: The application of electronic computers to factor analysis. Educ Psychol Meas 1960, 20, 141-151.

12. Kellon E.M.: Feeding the hoof. Equine nutritional solutions. Ephrata, Pennsylvania, USA 2008.

13. Ley W.B., Scott Pleasant R., Dunnington E.A.: Effects of season and diet on tensile strength and mineral content of the equine hoof wall. Equine Vet J 1998, 26, 46-50.

14. Łuszczyński J., Pieszka M., Durmała A., Pisarczyk W., Augustyn R., Długosz B.: Frequency of hoof conformation faults and disorders in horses of several breeds. Turk J Vet Anim Sci 2015, 39, 594-599.

15. Lynghaug F.: The Official Horse Breeds Standards Guide: the Complete Guide to the Standards of All North American Equine Breed Associations. Minneapolis, USA, 2009.

16. Martillotti F., Antongiovanni M., Rizzi L., Santi E., Bittante G.: Metodi di analisi per la valutazione degli alimenti d'impiego zootecnico. Quaderni metodologici n 8. Rome, Italy CNR-IPRA, 1987.

17. Muelling C.K.W. Nutritional influences on horn quality and hoof health. WCDS Adv Dairy Technol 2009, 21, 283-291.
18. Pütz A.C.: Monitoring of seasonal influences, the effect of housing conditions and domestication on the horn quality of the equine hoof. PhD Thesis, Fachbereich Veterinärmedizin, Freie Universität Berlin. Digitale Dissertationen der FU Berlin, Germany, 2006.

19. Roghi, M. Niente piede niente cavallo. Purosangue Arabo, marzo-giugno. Book of Abstracts, $19^{\text {th }}$ Congress, Cremona 1995.

20. Sáez A.G., Lozano E., Zaldívar-Riverón A.: Evolutionary history of Na, K-ATPases and their osmoregulatory role. Genetica 2010, 136, 479-490.

21. Sargentini C., Tocci R., Andrenelli L., Giorgetti A.: Preliminary studies on hoof characteristics in Amiata donkey. Ital J Anim Sci 2012, 11, 123-127.

22. SAS Institute Inc. JMP, Cary, USA, 2013.

23. Skibniewska E.M., Skibniewski M., Kośla T., Kołnierzak M. Concentrations of zinc, cadmium and lead in the hoof horn of the European bison (Bison bonasus bonasus). Ochr Srod Zas Nat 2015, 3, 32-35.

24. Smith Thomas H.: Understanding Equine Hoof Care: Your Guide to Horse Health Care and Management. Eclipse Press, Lexington, 2010.

25. Souza A.F., Kunz J.R., Laus R., Moreira M.A., Muller T.R., Fonteque J.H.: Biometrics of hoof balance in equids. Arq Bras Med Vet Zootec 2016, 68, 825-831.

26. Stachurska A., Kolstrung R., Pięta M., Silmanowicz P., Klimorowska A.: Differentiation between fore and hind hoof dimensions in the horse (Equus caballus). Arch Tierz 2008, 51, 531-540.

27. Stachurska A., Walkuska G., Cebera M., Jaworski Z., ChalabisMazurek A.: Heavy metal status of Polish Konik horses from stable-pasture and outdoor maintenance systems in the Masurian environment. J Elementol 2011, 16, 623-633.

28. Strasser H.: A lifetime of soundness, Ed \& Trans. Sabine Kell, Qualicum Beach BC, Canada 2000.

29. Tocci R., Sargentini C., Benedettini A., Benvenuti D., Pezzati A., Giorgetti A.: Physical and chemical properties on hoof of different equine breeds. In: Proceedings of the $12^{\text {th }}$ Congress dedicated to new findings in equine practice. Druento, Italy, 2010, pp. 62-65.

30. Tocci R., Sargentini C., Martini A., Giorgetti A.: Qualitative hoof characteristics in Anglo-Arabian horses and Monterufoli ponies reared in the same farm. Global J Anim Scient Res 2015, 3, 20-29.

31. Warren Evans J.: Horse breeding and management. The Netherlands Elsevier Science Publishers, Amsterdam 1992. 